\title{
Effect of Bilateral Versus Unilateral Use of Smartphone on Cross Sectional Area of Median Nerve
}

\author{
MAI E. MOUSA, M.Sc.*; RANIA R. ALI, Ph.D.*; MARWA Sh. MOSTAFA SALEH, Ph.D.* and \\ KHALED A. ABO DEWAN, Ph.D.** \\ The Department of Basic Science, Faculty of Physical Therapy, Cairo University* and \\ The Department of Neurology, Faculty of Medicine, Tanta University**
}

\begin{abstract}
Background: The use of smartphones and mobile devices has become widespread, particularly among youth, and the possible impacts on hand function and structures have not been clarified during bilateral and unilateral use of smartphone.

Aim of Study: This study was conducted to compare between bilateral and unilateral hand use of smartphone on cross sectional area of median nerve.

Subjects and Methods: Fifty-six students aged 18-25 years old were recruited from Faculty of Physical Therapy Kafr ElSheikh University. By using noninvasive ultrasonography, Cross Sectional Area (CSA) of median nerve was measured while subjects typed specific text on smartphone using bilateral hands then unilateral hand.

Results: The results revealed that the paired $t$-test show significant increase in CSA of median nerve in unilateral than bilateral hands use of smartphone as $t$-value was 55,000 and $p$-value was $p<.001$.

Conclusion: Unilateral hand use of smartphone has higher risk on CSA of median nerve so bilateral hands use of smartphone is recommended than unilateral hand use to reduce risk of Carpal tunnel syndrome.
\end{abstract}

Key Words: Cross sectional area - Median nerve - Smartphone.

\section{Introduction}

SMARTPHONES are becoming global, and mobile internet services are extensively used for various sorts of applications, including collaboration, e-learning, and much more. Long-term use of smartphones causes continuous mechanical stress on the tendons, muscles, nerves, and perimetric tissue, which can induce musculoskeletal

Correspondence to: Dr. Mai E. Mousa, The Department of Basic Science, Faculty of Physical Therapy, Cairo University symptoms, and Berolo et al., reported that mobile hand-held device users complain of discomfort in at least one area of the upper extremities, upper back, or neck [1-3]

Given the mobile nature of smartphones, users often hold the device with a single hand, which forces only the thumb to use the keys. In addition, it has been reported that university students spend, on average, $>3.5$ hours/day texting, e-mailing, scheduling, and internet browsing on their mobile phones. In a study on incidence of carpal tunnel syndrome in automobile workers, the annual incidence of CTS was found to be $10 \%$. Single-handheld smartphone use compels individuals to engage in repetitive flexion/extension of the wrist and thumb. These repetitive movements are involved in the etiopathogenesis of CTS because the median nerve is exposed to repetitive overload, and the median nerve enlarges [2,4-7]

Recent evidence has indicated that frequent smartphone users are more susceptible to have swollen median nerve, impaired hand function and reduced pinch strength. Using of smartphone can lead to CTS via affecting the median nerve. It has been reported by karlson that, $74 \%$ of all mobile hand-held device users most frequently used the device with a single hand. Few studies have focused on the actual methods of handling mobile devices, although it is known that the physical demands of one-handed use are greater than those of operation with two hands [8-11]

So in the present study, we investigated changes of CSA of median nerve of smartphone users operating a smartphone with bilateral hands and with unilateral hand, providing new data on smartphonerelated health problems. 


\section{Subjects and Methods}

Subjects: Fifty-six right handed healthy subjects (20 male and 36 females) aged from 18-25 years old were recruited from Faculty of Physical Therapy, Kafr El-Sheikh University in the period from October 2018 to December 2018.

\section{Inclusion criteria:}

All subjects were able to read and write in English \& using smartphone.

All subjects writes on smartphone by their thumb. Before the experiment, the purpose and procedures of the study were fully explained to all subjects, and all subjects subsequently voluntarily agreed to enroll in the present study. General characteristics of the subjects were measured age (20.36 \pm 1.6$)$ years, height $(167.18 \pm 9.66) \mathrm{cm}$, weight $(69.71 \pm 4.23) \mathrm{kg}$, and BMI $(24.04 \pm 3.27) \mathrm{kg} / \mathrm{m}^{2}$.

\section{Exclusion criteria:}

Subjects who had history of CTS including pain, tingling, burning, numbness, or a combination of these symptoms on the palmar aspect of the thumb, index finger, middle finger, or radial half of the ring finger, wrist surgery, underlying disorders associated with CTS including diabetes mellitus, rheumatoid arthritis, acromegaly, hypothyroidism, pregnancy, or obesity (body mass index $>30 \mathrm{~kg} / \mathrm{m}^{2}$ ), anatomic variations in the median nerve including bifurcation proximal to distal radioulnar junction, neck pain or spondylosis.

\section{Instrumentation:}

\section{Ultrasonography:}

High-resolution ultrasonography $(13 \mathrm{MHz} \mathrm{M}-$ Turbo system; SonoSite Inc., Bothell, Washington) [12].

\section{Methods:}

Transducer placement and procedure for measuring CSA of median nerve:

An ultrasound transducer was placed transversely at the level of carpal tunnel the ultrasound transducer was carefully held without applying any pressure on the participant's skin, and was maintained at an angle perpendicular to the median nerve. Median nerve CSA was determined by performing a boundary trace along the border between the hypoechoic inner median nerve and the hyperechoic outer epineurium [13].

\section{Measurements:}

A trained sonographer performed all ultrasound measurement while same smartphone was used in the study.
All participants were requested to sit on a chair facing the examiner with shoulder slightly abducted, the elbow of dominant hand flexed approximately at 90 , forearm rested on the table in partially supinated (approximately $45^{\circ}$ ) to enable them to assume a posture generally applied when using a smartphone for text messaging. During the ultrasound examination, participants were instructed to move their thumb and keep other parts of the hand still when writing on smartphone $[\mathbf{1 3 , 1 4}$.

An ultrasound transducer was placed transversely at the level of carpal tunnel to avoid undesirable physical contact of the flexing thumb or fingers with the transducer. The lunate bone was identified as the bony landmark for the correction of any minor hand movement that may occur during typing [13].

The subjects were typed (effect of smartphone) and repeated the phrase for one minute and ultrasound video was recorded then images will be captured from ultrasound video at carpal tunnel and the average was taken for determination of CSA of median nerve when using bilateral hands then unilateral hand.

\section{Data analysis:}

Measured data were analyzed and their mean values and standard deviation were calculated.

Paired sample- $t$-test was used to compare variables that measured in subjects. All statistical significance levels were $\alpha \leq 0.05$.

\section{Results}

\section{1-Demographic data:}

As shown in (Table 1) the study included 56 right handed subjects 20 male and 36 females as shown in Fig. (1), there mean age value was (20.36 \pm 1.6) years with minimum value of 18 and maximum value of 25 years, height mean value was $(167.18 \pm$ $9.66) \mathrm{cm}$ and it ranged from 148 to $186 \mathrm{~cm}$, weight mean value was $(69.71 \pm 12.35) \mathrm{kg}$ with minimum and maximum values of 45 and $91.5 \mathrm{~kg}$ respectively, and finally, subjects BMI mean value was (24.04 \pm $3.27) \mathrm{kg} / \mathrm{m}^{2}$ and it ranges between 18.14 and 29.71 $\mathrm{kg} / \mathrm{m}^{2}$.

\section{2- Statistical analysis of CSA of median nerve during bilateral hands Vs. unilateral hand use of smartphone:}

As shown in (Table 2) and Fig. (2) the mean value of CSA with two hands was $(0.502 \pm 0.094)$ $\mathrm{cm}^{2}$, while the mean value of CSA with one hand was $(0.582 \pm 0.091) \mathrm{cm}^{2}$. Statistically, there was statistically significant higher CSA of one hand in 
comparison to CSA of both hands ( $p$-value $<0.001$ ) with $13.7 \%$ percentage of difference.

Table (1): General characteristics of subjects.

\begin{tabular}{lllll}
\hline & Age & Weight & Height & BMI \\
\hline Minimum & 18 & 45 & 148 & 18.14 \\
Maximum & 25 & 91.50 & 186 & 29.71 \\
Mean & 20.36 & 67.44 & 167.18 & 24.04 \\
\pm S.D. & 1.60 & 12.35 & 9.66 & 3.27 \\
\hline
\end{tabular}

BMI: Body Mass Index.

Table (2): Comparison between CSA results using bilateral hands Vs. using unilateral hand.

\begin{tabular}{llc}
\hline & Bilateral hands & Unilateral hand \\
\hline Mean & 0.502 & 0.582 \\
+ S.D & 0.094 & 0.091 \\
Mean difference & 0.047 & \\
$\%$ of difference & 0.137 & \\
$t$-value & 55.000 & \\
$p$-value & $<0.001$ & \\
Level of significance & Significant increase & \\
\hline
\end{tabular}

SD : Standard Deviation.

$t$-value : Statistic $t$-test.

$p$-value : Probability.

: Significant at alpha level $<0.05$.

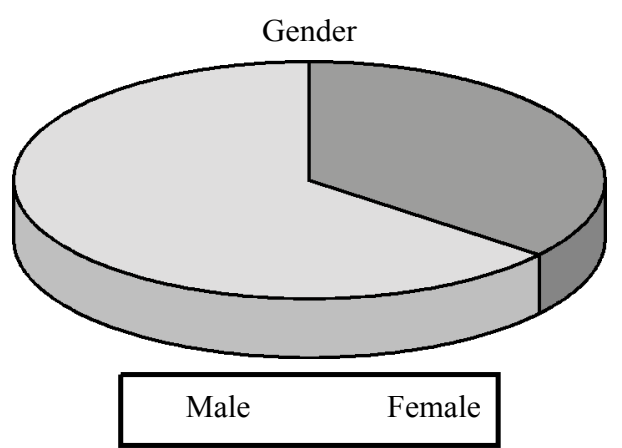

Fig. (1): Gender distribution.

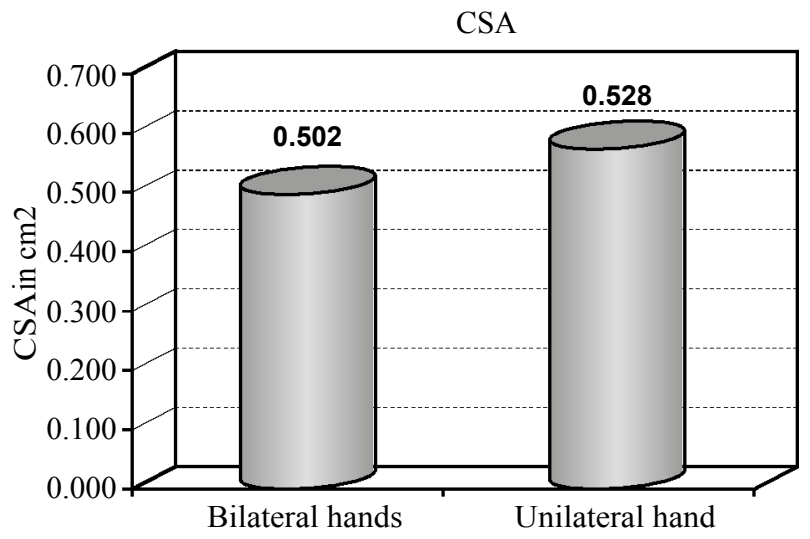

Fig. (2): Mean values during bilateral and unilateral hand use of smartphone.

\section{Discussion}

In the present study CSA of the median nerve was higher when the participants writing with one hand than both hands indicate that the morphology of the median nerve may be affected by rapid digit movement and the intensive thumb-tapping activity led to a swelling of the median nerve. Smartphone users typically adapt their thumb and hand postures to the constraints of the phone design layout that may impact their performance. Incorrect posture, such as repetitive use of the thumb, may impact the median nerve and the structures in the hand. the median nerve is exposed to repetitive overload, CTS may develop, and the median nerve enlarges $[5,7,15]$.

The results of the present study can be explained by the finding of Lai et al., who suggested that the median nerve became swollen after the students performed rapid mobile phone keying for $5 \mathrm{~min}$, indicated by a significant increase in the crosssectional area [14].

The results are in line with Inal et al., who stated that smartphone overuse enlarges the median nerve, causes pain in the thumb, and decreases pinch strength and hand functions especially Who have a habit of single-hand-held smartphone use. Also the results of this study agree with Woo et al., who reported that overuse of electronic devices enlarges the median nerve within the carpal tunnel, resulting in numbness, tingling, and pain in the hand $[\mathbf{8 , 1 6}]$.

The results of the present study was supported by those reported by Toosi et al., who found that acute increase in the area of the median nerve following $1 \mathrm{hr}$ of keyboarding with a computer keyboard. This suggests that keyboarding has an impact on the median nerve. Also the results of current study strengthened by Altinok et al., who concluded that immediately after provocative exercises imitating work-related stresses the nerve area at the middle level and the swelling ratio had significant higher. The results are in the line with Lee et al., who stated that smartphone use with both hands reduce the risk of musculoskeletal problems $[3,15,17]$.

Nevertheless, Impink et al., reported contradictory findings, in which a reduced cross-sectional area was observed after participants engaged in a wheelchair sporting activity. We postulate that such discrepancy may be caused by the difference in the nature of the activities: The wheelchair sporting activity involved solely upper-limb exercise and was more vigorous than mouse clicking and rapid 
keying, leading to a significant increase in carpal tunnel pressure that compensated for the swollen median nerve [18].

The results of current study not in agreement with Shim et al., who found that the median nerve circumference and area were decreased after subjects asked to use a smartphone for 30 minute, and the difference was statistically significant $(p<0.05)$. A reduction in the size of the space within the carpal tunnel was due to thickened muscles and ligaments after the use of smartphones, and, thus, these soft tissues pressed on the median nerve. that may be due to small sample size and different age group [19]

Also the results of current study disagree with Woo et al., who stated that performing different hand activities led to a gradual reduction in CSA of the median nerve, with thumb opposition together with the wrist in ulnar deviation causing the greatest extent of deformation of the median nerve. It may be due to the enlargement of tendons and soft tissues in the carpal tunnel that reducing the amount of space available for the movement of median nerve. That may be due to change position of wrist with movement of thumb [13].

\section{Conclusion:}

Unilateral hand use of smartphone has higher risk on CSA of median nerve so bilateral hands use of smartphone is recommended than unilateral hand use to reduce risk of carpal tunnel syndrome.

\section{References}

1- GAFNI RUTI and GERI NITZA: Do operating systems affect perceptions of smartphone advantages and drawbacks? In: Proceedings of the Informing Science and Information Technology Education Conference. Informing Science Institute, p. 175-84, 2013.

2- BEROLO S., WELLS R.P. and AMICK B.C.: Musculoskeletal symptoms among mobile hand-held device users and their relationship to device use: A preliminary study in a Canadian university population. Appl. Ergon., 42: 371-8, 2011.

3- LEE M., HONG Y., LEE S., WON J., YANG J., PARK S. and HONG Y.: The effects of smartphone use on upper extremity muscle activity and pain threshold. Journal of physical therapy science, 27 (6): 1743-5, 2015.

4- JONSSON P., JOHNSON P.W., HAGBERG M. and FORSMAN M.: Thumb joint movement and muscular activity during mobile phone texting-a methodological study. J. Electromyogr. Kinesiol., 21: 363-70, 2011.

5- TRUDEAU M.B., YOUNG J.G., JINDRICH D.L. and DENNERLEIN J.T.: Thumb motor performance varies with thumb and wrist posture during single-handed mobile phone use. J. Biomech., 2012.

6- WERNER .., FRANZBLAU A., GELL N., et al.: Incidence of carpal tunnel syndrome among automobile assembly workers and assessment of risk factors. J. Occup. Environ. Med., 47 (10): 1044-50, 2005.

7- BOWER J.A., STANISZ G.J. and KEIR P.J.: An MRI evaluation of carpal tunnel dimen sions in healthy wrists: Implications for carpal tunnel syndrome. Clin. Biomech. (Bristol., Avon), 21: 816-825, 2006.

8- iNAL E.E., DEMIRCI K., ÇETÎNTÜRK A., AKGÖNÜL M. and SAVA Ş S.: Effects of smartphone overuse on hand function, pinch strength, and the median nerve. Muscle Nerve, 52 (2): 183-8, 2015.

9- ILIK, FAIK, et al.: The effect of smartphone usage on the median nerve. Cukurova Medical Journal, 43 (1): 67 72, 2018.

10- KARLSON A.K., BEDERSON B.B. and CONTRERASVIDAL J.L.: Understanding single- handed mobile device interaction. HCIL Tech Report, Human-Computer Interaction Lab, University of Maryland, College Park, 2006.

11-KIM G.Y., AHN C.S., JEON H.W. and LEE C.R.: Effects of the use of smartphones on pain and muscle fatigue in the upper extremity. Journal of Physical Therapy Science, 24 (12): 1255-8, 2012.

12- SUCHER and BENJAMIN M.: Carpal tunnel syndrome: Ultrasonographic imaging and pathologic mechanisms of median nerve compression. Journal of the American Osteopathic Association, 109. 12: 641, 2009.

13- WOO, HOI-CHI, et al.: Development of kinematic graphs of median nerve during active finger motion: Implications of smartphone use. PloS one, 11 (7): 2349-54, 2016.

14- LAI W.K.C., CHIU Y.T. and LAW W.S.: The deformation and longitudinal excursion of median nerve during digits movement and wrist extension. Manual therapy, 19 (6): 608-13, 2014.

15-TOOSI, KEVIN K., et al.: Effects of computer keyboarding on ultrasonographic measures of the median nerve. American Journal of Industrial Medicine, 54 (11): 826-33, 2011.

16- WOO EUGENIA HOI CHI, WHITE PETER and LAI CHRISTOPHER WAI KEUNG: Effects of electronic device overuse by university students in relation to clinical status and anatomical variations of the median nerve and transverse carpal ligament. Muscle \& nerve, 56 (5): 87380, 2017.

17- ALTINOK M. TAYFUN, et al.: Sonographic evaluation of the carpal tunnel after provocative exercises. Journal of Ultrasound in Medicine, 23 (10): 1301-6, 2004.

18- IMPINK, BRADLEY G., et al.: Ultrasonographic median nerve changes after a wheelchair sporting event. Archives of physical medicine and rehabilitation, 90 (9): 1489-94, 2009.

19- SHIM J.M.: The effect of carpal tunnel changes on smartphone users. J. Phys. Ther. Sci., 4: 1251-3, 2012. 


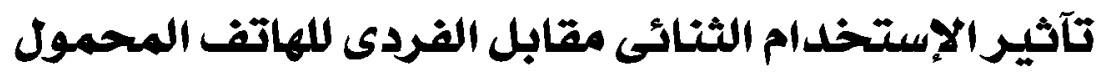

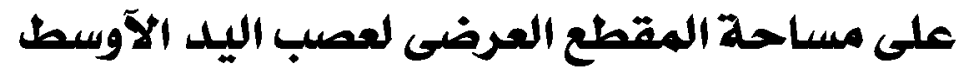

الخلفية: أصبح إستخدام الهواتف الذكية والآجهزة المحمولة واسبع الإنتشار، لا سيما بين الشباب، ولم يتم توضيح التآثيرات المحتملة

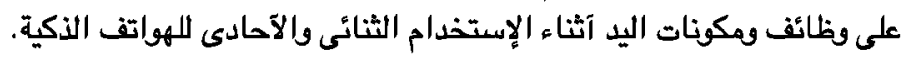

الفرض : آجريت هذه الدراسة للتحقيق والمقارنة بين الإستخدام الثنائى والآحادى للهواتف الذكية على منطقة المقطع العرضى لعصب اليد الآوبسط.

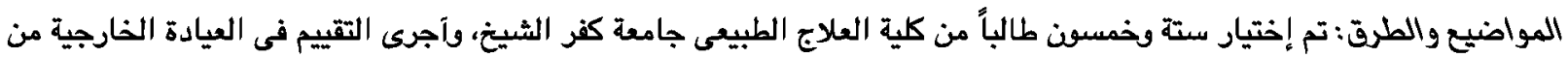

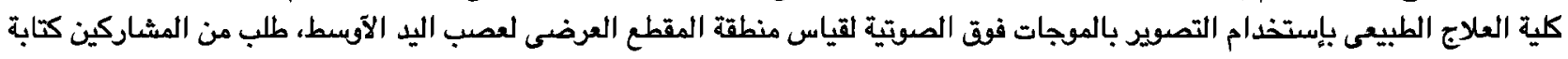
نص محدد بإستخدام يد واحدة وكلا اليدين على الهاتف المحمول آثناء قياس مساحة المقطع العرضى اللعصب الآوسط. النتائج : أظهرث النتائج آن إختبار t المقترن يظهر أن مساحة المقطع العرضى آثناء الإستخدام اليلوى الآحادى آكبر من الإستخدام الثنائى اللهاتف المحمول.

الخلاصدة: يمكن الإستتاج آن الإستخدام اليدوى الآحادى للهاتف المحمل له تآثير كبير فى مساحة المقطع العرضى لعصب اليد الآوبط

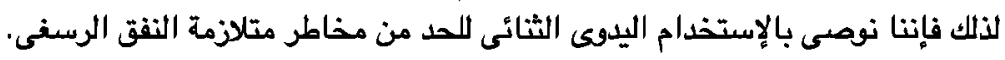

